\title{
EFFECT OF NUTRITIONAL COUNSELING LEAFLET MEDIA ON KNOWLEDGE, SODIUM, POTASIUM INTAKE IN HYPERTENSION PATIENTS
}

\author{
Dina Dwi Aprilia', Jumiyati ${ }^{1}$, Ayu Pravita Sari ${ }^{1}$ \\ ${ }^{1}$ Jurusan Gizi,Poltekkes Kemenkes Bengkulu, Indonesia \\ E-mail: Dinadwiaprilia2704@gmail.com, Yatijumi70@yahoo.co.id
}

Submitted: 20 $0^{\text {th }}$ July 2020; Accepted: $5^{\text {th }}$ August 2021

https://doi.org/10.36525/sanitas.2021.6

\begin{abstract}
ABSTRACK
Hypertension actually is a disease that can be implified on sudden death. It's mostly caused by high blood pressure so that the risk of suffering complications is a big issue. It can be caused by many factors, one of that is high sodium and low potassium consumption as well.The purpose of this study determines the effect of nutritional counseling using modified leaflet media, knowledge of sodium and potassium intake in patients with hypertension in Basuki Rahmad Community Health Center in Bengkulu City in 2020.This research method is a pre-experimental research design with one group pretest and posttest term. Samples that were taken by purposive sampling of 25 people. Data collected includes pre test data first, namely knowledge, data, sodium intake, and potassium. After that post-test data, it is knowledge data about sodium and potassium consumption. Analysis of the data used is the univariate analysis and bivariate analysis.Based on the research from 25 samples given nutritional counseling, the results obtained knowledge about sodium and potassium consumption value of p-value 0,000 .In the conclusion of this study is about the influence of nutritional counseling on sodium and potassium consumption that related to hypertension disease.
\end{abstract}

Keywords : knowledge, sodium intake, potassium intak.

This is an open access journal, and articles are distributed under the terms of the Creative Commons Attribution-Non Commercial-Share Alike 4.0 License, which allows others to remix, tweak, and build upon the work non-commercially, as long as appropriate credit is given and the new creations are licensed under the identical terms.

C2021 Sanitas 


\title{
PENGARUH KONSELING GIZI MENGGUNAKAN MEDIA LEAFLET TERHADAP PENGETAHUAN, ASUPAN NATRIUM DAN KALIUM PADA PENDERITA HIPERTENSI
}

\begin{abstract}
ABSTRAK
Hipertensi merupakan penyakit yang dapat menyebabkan kematian mendadak yang diakibatkan oleh semakin tingginya tekanan darah sehingga resiko untuk menderita komplikasi semakin besar. Berkembangnya hipertensi dipengaruhi oleh banyak faktor, salah satunya asupan natrium tinggi dan rendahnya asupan kalium, untuk mencegah terjadinya hipertensi dilakukan konseling gizi. Penelitian ini bertujuan untuk mengetahui pengaruh konseling gizi menggunakan media leaflet modifikasi terhadap pengetahuan, asupan natrium dan kalium pada penderita hipertensi. Metode penelitian ini adalah penelitian pra eksperimen dengan rancangan one group pretest posttest design. Sampel diambil secara purposive samplingsebanyak 25 orang. Data yang dikumpulkan meliputi pengetahuan asupan natrium dan kalium menggunakan instrumen penelitian kuesioner dan formrecall. Analisis data yang digunakan adalahn uji wilcoxson.Berdasarkan hasil penelitian dari 25 sampel yang diberikan konseling gizi didapatkan hasil pengetahuan, asupan natrium dan asupan kalium nilai $p$-value 0,000. Kesimpulan dari penelitian ini yaitu adanya pengaruh konseling gizi terhadap asupan natrium dan asupan kalium pada penderita hipertensi.
\end{abstract}

Kata kunci: pengetahuan, asupan natrium, asupan kalium

\section{PENDAHULUAN}

Hipertensi di Indonesia merupakan masalah yang besar dan serius disamping karena prevalensinya yang tinggi dan cenderung meningkat di masa yang akan datang karena tingkat keganasannya yang tinggi berupa kecacatan permanen dan kematian mendadak (1). Organisasi Kesehatan Dunia (WHO) mencatat pada tahun 2012 sejumlah, diperkirakan menjadi 1,15 milyar pada tahun 2025 atau sekitar 29\% dari total penduduk dunia, dimana penderitanya lebih banyak pada wanita (30\%) dibandingkan pria (29\%). Sekitar 80\% kenaikan kasus hipertensi terjadi terutama di negara-negara berkembang (2). Data Riskesdas tahun 2018 menunjukkan prevelensi hipertensi di indonesia sebesar $34,1 \%$. Data tersebut mengalami kenaikan yang cukup signifikan dibandingkan dengan data hasil Riskesdas tahun 2013 yaitu sebesar 25,8\% (3). Berdasarkan data dari Profil kesehatan di provinsi Bengkulu tahun 2018 didapatkan bahwa 2018 jumlah estimasi penderita $\geq 15$ tahun mencapai 899.010 jiwa (4) Hipertensi tertinggi terdapat di Wilayah Kecamatan Selebar Puskesmas Basuki Rahmad pada laki-laki 3.292 jiwa dan pada perempuan 4.172 jiwa (5).

Salah satu faktor penyebab hipertensi adalah asupan natrium tinggi dan rendahnya asupan kalium. Kadar natrium yang terus meningkat di dalam tubuh dapat mengakibatkan fungsi ginjal terganggu. Natrium menumpuk di dalam darah dan 
membuat jantung dan pembuluh darah bekerja lebih keras untuk memompa darah dan mengalir keseluruh tubuh, sehingga tekanan darah meningkat. Kalium memelihara keseimbangan cairan, elektrolit dan asam basa. Kalium dapat menurunkan tekanan darah, hal ini dapat menghambat terjadinya konstriksi pembuluh darah yang dapat menyebabkan penurunan resistensi perifer sehingga dapat menurunkan tekanan darah (5) Hasil penelitian yang dilakukan oleh Krummel, terdapat hubungan yang bermakna antara konsumsi natrium yang tinggi dapat menyebabkan hipertensi dibandingkan dengan konsumsi tinggi kalium (6).

Kalium juga berperan dalam terjadinya tekanan darah. Bersama natrium, kalium memegang peranan dalam pemeliharaan keseimbangan cairan dan elektrolit serta keseimbangan asam basa. Kadar kalium yang tinggi dapat meningkatkan ekskresi natrium dalam urin (natriuresis), sehingga dapat menurunkan volume darah dan tekanan darah. Penurunan kalium dalam ruang intrasel menyebabkan cairan dalam ruang intrasel cenderung tertarik keruanganekstrasel dan retensi natrium (4). Menurut Makrawung (2016) terdapat penurunan tingkat asupan natrium sesudah diberikan konseling.

Kejadian hipertensi di Indonesia dapat dikurangi dengan cara meningkatkan pengetahuan individu mengenai hipertensi. Pengetahuan kesehatan akan berpengaruh pada indikator kesehatan masyarakat. Pengetahuan, dan perilaku terhadap penyakit hipertensi mempunyai peranan penting dalam pencegahan, pengendalian dan pengobatan pasien hipertensi. Karena dengan pengetahuan pasien tentang penyakit ini, akan merubah perilaku pasien yang turut berperan mensukseskan pengobatan (5). Peningkatan pengetahuan dapat dilakukan dengan memberikan konsultasi gizi. Konsultasi gizi termasuk suatu bentuk pendekatan yang digunakan dalam asuhan gizi untuk menolong individu dan keluarga memperoleh pengertian yang lebih baik tentang dirinya dan permasalahan yang dihadapi. Informasi yang diperoleh dari konseling gizi dapat membantu individu dan keluarga untuk mengambil langkah- langkah dalam mengatasi masalah (5).

Media yang digunakan untuk konsultasi gizi yaitu Leaflet modifikasi. Leaflet merupakan selembaran kertas yangberisikan tentang informasi khusus dan didukung 
oleh gambar dengan tujuan pembaca dapat memahami langsung isi dari leaflet. Leaflet merupakan salah satu media yang efektif dalam mempengaruhi perilaku seseorang. Hasil penelitian di natunadiperoleh hasil sebanyak $67 \%$ leaflet efektif dalam mempengaruhi perilaku seseorang (6)

Penelitian ini bertujuan untuk mengetahui pegaruh konseling gizi menggunakan media leaflet modifikasi terhadap pengetahuan, asupan natrium dan kalium pada penderita hipertensi di wilayah kerja Puskesmas Basuki Rahmad Kota Bengkulu Tahun 2020. Berdasarkan latar belakang tersebut, peneliti tertarik untuk meneliti pengaruh konseling gizi menggunakan media leaflet modifikasi terhadap pengetahuan, asupannatrium dan kalium pada penderita hipertensi.

\section{METODE PENELITIAN}

Metode penelitian ini adalah penelitian pra eksperimen dengan rancangan one group pretest posttest design. Rancangan jenis ini hanya menggunakan satu kelompok intervensi, Perlakuan yang diberikan yaitu konseling gizi tentang hipertensi menggunakan media leaflet modifikasi yang dilakukan satu minggu satu kali selama 3 minggu. Data pretest diberikan sebelum pemberian konsultasi gizi dan posttest setelah ada perlakuanakan dilakukan seminggu setelah konsultasi gizi. Sampel dalam penelitian ini berjumlah 25 orang. Peneliti memilih sampel menggunakan purposive sampling. Analisis data menggunakan uji Wilcoxon.

Intrumen penelitian ini menggunakan lembar kuesioner yang berisikan tentang pengetahuan hipertensi, bahan makanan untuk penderita. Instrumen yang digunakan untuk melihat asupan natrium dan asupan kalium menggunakan form recall 1x24 jam, yang diukur sebanyak 2 kali, untuk mengetahui hasil asupan natrium, kalium menggunakan aplikasi nutrisurvei dan media konseling menggunakan leaflet modifikasi yang berisikan tentang pengetahuan hipertensi,makanan penderita hipertensi, contoh menu, makanan yang di anjurkan dan tidak di anjurkan pada penderita hipertensi.

\section{HASIL DAN PEMBAHASAN}

Tabel 1 Distribusi frekuensi pengetahuan, asupan natrium dan kalium 


\begin{tabular}{lccccc}
\hline \multirow{2}{*}{ Variabel } & \multicolumn{3}{c}{ Pre } & \multicolumn{2}{c}{ Post } \\
\cline { 2 - 6 } & $\mathrm{n}$ & Min \pm Max & Mean \pm SD & Min \pm Max & Mean \pm SD \\
Pengetahuan & 25 & $30 \pm 70$ & $49,2 \pm 1,11$ & $70 \pm 100$ & $86,4 \pm 0,86$ \\
Asupan natrium $(\mathrm{Mg})$ & 25 & $1408 \pm 2267$ & $1868 \pm 275,85$ & $963 \pm 2190$ & $1392 \pm 341,83$ \\
Asupan kalium $(\mathrm{Mg})$ & 25 & $751 \pm 1887$ & $1471 \pm 302,34$ & $949 \pm 2696$ & $2185 \pm 509,33$ \\
\hline
\end{tabular}

Tabel 1 Menunjukkan bahwa nilai pengetahuan minimal responden hipertensi sebelum diberikan konseling gizi yaitu 30 dan nilai maksimum adalah 70 dengan rata- rata 49,2 setelah di berikan konseling gizi nilai minimal adalah 70 dan nilai maksimum adalah 100 dengan rata - rata meningkat yaitu 86,4. Asupan natrium menunjukkan nilai asupan natrium minimal sebelum diberikan konseling gizi adalah $1,408 \mathrm{mg} /$ hari dan nilai maksimum adalah 2,267 dengan rata - rata $1,868 \mathrm{mg} /$ hari sedangkan nilai asupan natrium setelah diberikan konseling gizi nilai minimal adalah $963 \mathrm{mg} /$ hari dan nilai maksimal adalah 2,190 mg/ hari dan rata- rata asupan natrium menurun yaitu 1392 mg/ hari. Asupan kalium menunjukkan nilai minimal asupan kalium sebelum diberikan konseling gizi adalah $751 \mathrm{mg} / \mathrm{hari}$ dan nilai maksimal $1887 \mathrm{mg} /$ hari dengan rata- rata asupan kalium 1,471 mg/ hari sedangkan nilai minimal asupan kalium sesudah diberikan konseling gizi adalah $949 \mathrm{mg} / \mathrm{hari}$ dan nilai maksimal 2,696 dan nilai rata-rata asupan kalium meningkat yaitu 2,185 mg/ hari.

\section{Tabel 2 pengaruh konseling gizi menggunakan media leaflet modifikasi terhadap} pengetahuan, asupan natrium dan kalium

\begin{tabular}{lcccc}
\hline \multirow{2}{*}{ Variabel } & $\mathrm{n}$ & Pre & Post & P \\
\cline { 3 - 4 } & & Mean \pm SD & Mean \pm SD & \\
\hline Pengetahuan & 25 & $49,2 \pm 1,11$ & $86,4 \pm 0,86$ & 0,000 \\
\hline Asupan natrium (mg) & 25 & $1868 \pm 275,85$ & $1392 \pm 341,83$ & 0,001 \\
\hline Asupan kalium(mg) & 25 & $1471 \pm 302,34$ & $2185 \pm 509,33$ & 0,000 \\
\hline \#uji wilcoxson & & & &
\end{tabular}

\#uji wilcoxson

Berdasarkan tabel 2 hasil uji statistik dengan menggunakan uji wilcoxonmenunjukkan nilai rata-rata pengetahuan responden sebelum diberikan konseling gizi adalah 49,2 dengan standar deviasi 1,11 sedangkan setelah diberikan konseling gizi di dapatkan nilai mean responden 86,4 dengan standar deviasi 0,86. Pada hasil uji statistik terhadap asupan natrium menunjukkan nilai rata-rata asupan natrium sebelum diberikan konseling gizi adalah 1868 
$\mathrm{mg}$ /hari dengan standar deviasi yaitu 275,85 sedangkan setelah diberikan konseling gizi rata - rata asupan natrium $1.392 \mathrm{mg} /$ hari dengan standar deviasi 341,83. Hasil uji statistik asupan kalium sebelum diberikan konseling gizi rata- rata asupan kalium $1.471 \mathrm{mg} / \mathrm{hari}$ dengan standar deviasi 302,34 dan setelah diberikan konseling gizi rara - rata nilai asupan kalium yaitu $2.185 \mathrm{mg}$ / hari dengan standar deviasi 509,33.

Hasil uji statistik pengetahuan, asupan natrium, dan asupan kalium ( $p$ value $=0,000$ ) didapatkan nilai $p<0,05$, maka dapat disimpulkan ada pengaruh yang signifikan terhadap pengetahuan, asupan natrium dan kalium responden sebelum dan sesudah diberikan konseling gizi menggunakan media leaflet modifikasi.

\section{Pengetahuan}

Berdasarkan tabel 2 tingkat pengetahuan sesudah diberikan konseling gizi menggunakan leaflet modifikasi mengalami peningkatan tingkat pengetahuan. Rata-rata tingkat pengetahuan sebelum skor 4,92 dan setelah diberikan konseling gizi tingkat pengetahuan dengan skor 8,64. Pada penelitian ini sebagian besar responden mempunyai pengetahuan yang kurang terkait penyakit hipertensi dibuktikan dengan responden menjawab dari sepuluh pertanyaan $64 \%$ responden menjawab mendapat nilai $<50$. Adapun pengetahuan responden masih kurangnya pengetahuan tentang makanan yang mengandung natrium tinggi dan kurang memahami bahan makanan yang baik pada penderita hipertensi. Namun setelah diberikan konseling gizi terdapat peningkatan pengetahuan dibuktikan dengan 92\% responden dapat menjawab pertanyaan dengan hasil skor $>80$. Kuesioner yang diberikan disesuaikan dengan leaflet yang menjadi media konseling gizi, sehingga semua petanyaan dapat dipelajari oleh responden mengenai hipertensi walaupun setelah diberikan konseling gizi.

Hasil penelitian ini sesuai dengan penelitian Febriyana, (2016) di kota Matarammenyatakan terdapat perbedaan yang signifikan terhadap tingkat pengetahuan sebelum dan sesudah diberikan konseling gizi selama 1 bulan dan salah satu faktor penyebab meningkatnya pengetahuan yaitu tingkat pendidikan responden (7). Hasil penelitian ini menunjukkan bahwa konseling gizi dapat meningkatkan pengetahuan pada penderita 
hipertensi. Hal ini sesuai dengan penelitian Quercioli, (2011) menyatakan adanya pengaruh konseling gizi terhadap pengetahuan zat gizi di eropa yang dimana hasil persentase pengetahuan gizi meningkat dari 64\% menjadi $78 \%$ (8).

Penelitian ini juga sesuai dengan penelitian Nurlita, (2017) di Makasar, menyatakan ada peningkatan pengetahuan $(\mathrm{p}=0,000)$ sebelum dan sesudah diberikan konseling gizi dengan media leaflet modifikasi. Peningkatan skor yang terjadi setelah konseling menunjukkan bahwa tujuan konseling tercapai. Sesuai dengan teori edukasi yang menyatakan bahwa konseling merupakan media untuk mendidik pasien responden sehingga pengetahuan responden meningkat dan hal ini mendorong untuk perubahan perilaku (9).

Konseling dapat membantu responden mengidentifikasi dan menganalisis masalah responden serta memberikan alternatif dalam pemecahan masalah responden. Tingkat pengetahuan yang baik tentang hipertensi akan mempermudah terjadinya perubahan perilaku. Hal ini sesuai dengan teori yang menyatakan bahwa salah satu faktor penentu terjadinya perubahan perilaku kesehatan adalah adanya faktor pengetahuan mengenai hipertensi.Informasi atau pengetahuan yang di dapatkan secara berulang dapat meningkatkan pengetahuan (9).

\section{Asupan Natrium}

Berdasarkan tabel 2 dapat disimpulkan bahwa terdapat penurunan rata- rata asupan natrium setelah diberikan konseling gizi selama 3 minggu. Asupan natrium sebelum diberikan konseling gizi 1,868 mg/hari sedangkan rata- rata asupan natrium setelah diberikan konseling gizi menurun yaitu $1,392 \mathrm{mg} /$ hari. Nilai tersebut menunjukkan adanya pengaruh asupan natrium setelah diberikan konseling gizi menggunakan media leaflet modifikasi dengan nilai $p=0,001$.

Penelitian Hasbulah, (2017) yang menyatakan adanya perbedaan rata- rata asupan pada responden yang mengalami penurunan asupan natrium setelah diberikan konseling gizi menggunakan media leaflet (10). Asupan natrium responden dilihat dari recall 2 x 24 jam hasil yang di dapatkan darirecall saat penelitian responden sering mengkonsumsi bahan makanan yang mengandung tinggi natrium. Lima bahan makanan yang paling sering di 
konsumsi respoden antara lain garam, ikan asinatau teri, saos, kecap dan mie instan. Berdasarkan hasil penelitian miftahahul jannah, (2013) menyatakan konsumsi garam yang tinggi merupakan salah satu faktor penyebab hipertensi dikota Padang (11).

Hasil penelitian Xu Ji dkk di Cina, (2017) menyatakan bahwa konsumsi garam dalam jumlah yang tinggi dapat memperkecil diameter arteri, sehingga jantung harus memompa lebih keras untuk mendorong volume darah yang meningkat melalui ruang yangsemakin meningkat dan akan menyebabkan tekanan darah meningkat (12). Penelitian ini sejalan dengan penelitian Stella, (2017) menyatakan jenis makan yang sering dikonsumsi adalah ikan teri, ikan laut, ayam, telur dan garam. Natrium yang menimbulkan retensi cairan dan meningkatkan tekanan darah. Berdasarkan penelitian Atun, (2016) menyatakan bahwa hasil asupan natrium yang tinggi berhubungan dengan kejadian hipertensi (13). Menurut kemenkes, (2013) prevelensi konsumsi makanaan asin di provinsi bengkulu sebesar 21,5\% (14).

Berdasarkan teori,asupan zat natrium merupakan nutrisi paling penting untuk mempertahankan volume darah, mengatur keseimbangan air dalam sel, dan menjaga fungsi saraf. Ginjal mengontrol keseimbangan natrium dengan meningkatkan dan menurunkan natrium dalam urin. Kelebihan konsumsi natrium secara terus menerus dapat menyebabkan terjadinya hipertensi.

\section{Asupan Kalium}

Hasil tabel 2 dapat disimpulkan bahwa terdapat peningkatan asupan kalium sesudah diberikan konseling gizi selama 3 minggu menggunakan media leaflet modifikasi. Hasil uji statistik di dapatkan rata- rata asupan kalium sebelum diberikan konseling gizi 1,471 mg/hari, sedangkan rata-rata asupan kalium setelah diberikan konseling gizi 2,185mg/hari. Asupan kalium responden dapat dilihat dari recall 2 x 24 jam dengan metode wawancara didapatkan hasil rata-ratanya kurang dari kebutuhan atau yang dianjurkan masih dibawah normal $(<4700) \mathrm{mg} / \mathrm{hr}$ tetapi sudah ada peningkatan asupan. Hasil recall didapatkan responden masih kurang mengkonsumsi bahan makanan yang mengandung kalium seperti sayur dan buah. Lima bahan makanan tinggi kalium yang sering dikonsumsi responden adalah, buah pisang,pepaya, sayur bayam, kankung, wortel. 
Menurut Hasbullah, (2017) di kecamatan di kartasura, hipertensi bisa dikendalikan melalui pola makan dan diet yang tepat. Hipertensi yang terkontrol dengan baik dapat meminimalkan dampak yang terjadi.Penderita hipertensi dianjurkan meningkatkan asupan tinggi kalium (6). Hasil penelitian Maria, (2017) menyatakan pisang dan pepaya dapat menurunkan tekanan darah di kota baitung berdasarkan penelian Francona, menyatakan bahwa buah dan sayuran dapat menurunkan tekanan darah hal ini dikarenakan menyebabkan vasodilatasi sehingga terjadi penurunan resistensi perifer, kalium juga menghambat proses konvensi pelepasan renin menjadi rennin- angiotensin sehingga tidak terjadi peningkatan tekanan darah (15).

Hasil penelitian ini sesuai dengan penelitian Suwarni, (2008) di Kabupaten Konawe, yang melakukan penelitian dengan waktu konseling 5-10 menit dengan media leaflet menyatakan terdapat peningkatan asupan kalium $(p=0,000)$ sesudah diberikan konseling gizi (10). Menurut hardiansyah dkk pendidikan gizi dapat membantu setiap individu dan masyarakat dalam praktik perilaku hidup sehat dengan cara memberikan informasi memberikan informasi terkait perilaku makan.

Menurut Wahyuningsih, (2013) secara fisiologi kalium memiliki peranan dalam mengurangi resiko hipertensi. Asupan kalium yang banyak dapat menurunkan tekanan darah. Asupan Kalium pada seseorang dapat mempengaruhi tekanan darah, Kalium dapat membantu menurunkan tekanan darah tinggi. Kadar kalium yang tinggi dapat meningkatkan ekskresi natrium dalam urin (natriuresis), sehingga dapat menurunkan volume darah dan tekanan darah. Penurunan kalium dalam ruang intrasel menyebabkan cairan dalam ruang intrasel cenderung tertarik keruangekstrasel dan retensi natrium (16).

\section{KESIMPULAN}

Pengetahuan responden sebelum dan sesudah diberi konseling gizi terdapat perubahan skor sebesar 37,2. Untuk asupan natrium terjadi penurun sebelum dan sesudah diberi konseling gizi sebesar $476 \mathrm{mg} / \mathrm{hari}$, sedangkan asupan kalium terjadi peningkatan yaitu 714 $\mathrm{mg} / \mathrm{hari}$ sebelum dan sesudah diberikan konseling gizi. Ada pengaruh konseling gizi menggunakan media leaflet modifikasi terhadap tingkat pengetahuan, asupan natrium dan asupan kalium. 
Disarankan kepada responden untuk mengurangi asupan natrium $1500 \mathrm{mg} / \mathrm{hari}$ dan dapat meningkatkan asupan kalium 4700mg/hari. Untuk peneliti selanjutnya di harapkan dapat menambah variabel lain seperti variabel sikap, asupan magnesium, asupan lemak yang berpengaruh terhadap penderita hipertensi.

\section{DAFTAR PUSTAKA}

1. Pratami F, Dewi RM. Perbedaan Pengetahuan Pasien Penderita Hipertensi Sebelum Dan Sesudah Diberikan Konsultasi Gizi. J Keperawatan. 2016;XII:1:58-65.

2. Yuliantini E, Maigoda Tc. Impact Of Sports And Nutrition Counseling To Blood Pressure And Nutritional Status Based On Waist Circumference In Hypertensive Patients At Bengkulu. 2011.

3. Riskesdas. Riset kesehatan dasar nasional. Jakarta: badan penelitian dan pengembangan kesehatan dapertemen kesehatan republik indonesia.

4. Profil Kesehatan Provinsi Bengkulu Tahun 2018. Bengkulu. Dinas KesehatanProvinsi Bengkulu.

5. Demiyanti E, Raksanagara AS, Afriandi I. Pengaruh Edukasi Kelompok pada Pengendalian Tekanan Darah di Anggota Klub Prolanis Klinik Pratama The Influence of Group Education Upon Blood Pressure Control Among Prolanis Club Members in Primary Care Clinic. 2017;4:47-51.

6. Mahmudah S, Maryusman T, Arini FA, Malkan I. Hubungan Gaya Hidup Dan Pola Makan Dengan Kejadian Hipertensi Pada Lansia Di Kelurahan Sawangan Baru Kota Depok Tahun 2015. Biomedika. 2015;2:43-51.

7. Periode S, April F. Hipertensi Di Instalasi Rawat Jalan Rsud Dr . Moewardi Hipertensi Di Instalasi Rawat Jalan Rsud Dr . Moewardi. 2018;(April).

8. Quercioli. Nutritional Counseling And Its Effects On Diet, Nutritional Knowlwdge And Status, Physical Activity And Quality Of Life In A Southern Europe Population: Evaluation Of A Healt Promotion Programme. Italian Journal Of Public Health.2011.

9. Nurlita N, Nelli S, Lipinwati D. M. B, \& Biomed, M. Pengetahuan Pasien Hipertensi Terhadap Diet Rendah Garam Sebelum Dan Sesudah Diberikan Konsultasi Gizi Di Poli Gizi Rumah Sakit Raden Mattaher Tahun 2017.Jmj.201:2: 117 - 126.

10. Hasballah K, Tahlil T. Pengetahuan, Sikap, Dan Perilaku Diet Hipertensi Lansia Di Aceh Selatan Knowledge, Attitude, and Behavior about Hypertension Diet among Elderly in South Aceh. 2017.

11. Mifthahul J. Perbedaan Asupan Natrium Dan Kalium Pada Penderita Hipertensi Dan Normotensi Masyarakat Etnik Minang Kabau Kota Padang. Fakultas Kedokter 
Universitas Andalas.2013.

12. $\mathrm{Xu}$ ju. Associations of usual 24-hour sodium and pottasium intakes with blood pressure and risk of hypertension among adults in china's shandong and blood presurre research. 2017:42(1):188-200.

13. Atun. Asupan Sumber Natrium, Rasio Kalium Natrium, Aktivitas Fisik, Dan Tekanan Darah Pasien Hipertensi. Arch Zootec. 2016;65:249:63-71.

14. Kemenkes RI. Laporan Hasil Riset Kesehatan Dasar (Riskesdas) Indonesia Jakarta.2013.

15. Maria, F. Pemberian buah pepaya segar dan penurunan tekanan darah sistolik dan diastolik pada penderita hipertensi: politeknik poltekkes kemenkes semarang.2017

16. Wahyuningsih. Penatalaksanaan Diet Pada Pasien. Graha ilmu. Yogyakarta.2017. 